medRxiv preprint doi: https://doi.org/10.1101/2021.08.10.21261846; this version posted August 11, 2021. The copyright holder for this preprint (which was not certified by peer review) is the author/funder, who has granted medRxiv a license to display the preprint in perpetuity.

All rights reserved. No reuse allowed without permission.

\title{
Impact of the COVID-19 Pandemic on Early Child Cognitive Development: Initial Findings in a Longitudinal Observational Study of Child Health
}

\author{
Sean CL Deoni ${ }^{1,2,3}$, Jennifer Beauchemin ${ }^{1}$, Alexandra Volpe ${ }^{1}$, Viren D'Sa ${ }^{1,2}$, and the RESONANCE \\ Consortium
}

1 Advanced Baby Imaging Lab, Rhode Island Hospital, Providence RI, USA

2 Department of Pediatrics, Warren Alpert Medical School at Brown University, Providence RI, USA

3 Department of Diagnostic Radiology, Warren Alpert Medical School at Brown University, Providence RI, USA

Address Correspondence to: Sean Deoni

Advanced Baby Imaging Lab

Rhode Island Hospital

Warren Alpert Medical School at Brown University

Email: sean_c_deoni@brown.edu

Running Title: The COVID-19 Pandemic and Child Cognitive Development

Manuscript prepared for Submission to Developmental Cognitive Neuroscience.

Keywords: COVID-19; Child Development; Cognitive Development; Maternal Stress;

\section{Funding}

1. Environmental Influences on Child Health Outcomes (ECHO) National Institutes of Health (SCD UG3OD023313);

2. National Institutes of Health (SCD R34-DA050284);

The RESONANCE Consortium consists of:

Joseph Braun, Brown University School of Public Health, Brown University.

Kevin Bonham, Wellesley College.

Vanja Klepac-Ceraj, Wellesley College.

Matthew Huentelman, Neurobehavioral Research Unit, TGen;

Candace Lewis, Neurobehavioral Research Unit, TGen;

Monique LeBourgeois, Integrative Physiology, University of Colorado at Boulder;

Hans-Georg Müller, Department of Statistics, University of California at Davis;

Jane-Ling Wang, Department of Statistics, University of California at Davis;

Susan Carnell, Associate Professor of Psychiatry and Behavioral Sciences, Johns Hopkins University; 
medRxiv preprint doi: https://doi.org/10.1101/2021.08.10.21261846; this version posted August 11, 2021. The copyright holder for this preprint (which was not certified by peer review) is the author/funder, who has granted medRxiv a license to display the preprint in perpetuity.

\section{ABSTRACT}

Since the first reports of novel coronavirus in the 2020, public health organizations have advocated preventative policies to limit virus, including stay-at-home orders that closed businesses, daycares, schools, playgrounds, and limited child learning and typical activities. Fear of infection and possible employment loss has placed stress on parents; while parents who could work from home faced challenges in both working and providing full-time attentive childcare. For pregnant individuals, fear of attending prenatal visits also increased maternal stress, anxiety, and depression. Not surprising, there has been concern over how these factors, as well as missed educational opportunities and reduced interaction, stimulation, and creative play with other children might impact child neurodevelopment. Leveraging a large on-going longitudinal study of child neurodevelopment, we examined general childhood cognitive scores in 2020 and 2021 vs. the preceding decade, 2011-2019. We find that children born during the pandemic have significantly reduced verbal, motor, and overall cognitive performance compared to children born pre-pandemic. Moreover, we find that males and children in lower socioeconomic families have been most affected. Results highlight that even in the absence of direct SARS-CoV-2 infection and COVID-19 illness, the environmental changes associated COVID-19 pandemic is significantly and negatively affecting infant and child development. 
medRxiv preprint doi: https://doi.org/10.1101/2021.08.10.21261846; this version posted August 11, 2021. The copyright holder for this preprint (which was not certified by peer review) is the author/funder, who has granted medRxiv a license to display the preprint in perpetuity. All rights reserved. No reuse allowed without permission.

\section{INTRODUCTION}

Since the beginning in March of 2020, the outbreak of the SARS-CoV-2 (COVID-19) pandemic in the USA, and the accompanying economic shut-down has brought about significant upheavals to the social, economic, and public health environments in which children live, grow and play. While children, and those under age 5, have largely been spared from the severe health and mortality complications associated with SARS-CoV-2 infection [1, 2], they have not been immune to the impact of the stay-athome, masking, and social distancing policies. These policies, meant to limit spread of the SARSCoV-2 virus, have closed daycares, schools, parks, and playgrounds [3, 4], and have disrupted children's educational opportunities [ 5], limited explorative play and interaction with other children [6], and reduced physical activity levels [7]. From the beginning of the pandemic, there has been concern that these public-health policies would adversely impact infant and early child development and mental health. While there is no past analogue or example of non-conflict related wide-spread and prolonged lock-downs from which to draw information from, concern for child development stemmed principally from the known impact that family and home stress, parent and child anxiety, lack of stimulating environments, and other economic and environmental adversities can have on the developing infant and child brain [8, 9].

Like many other states and regions in the United States, elementary, secondary, and post-secondary schools were closed throughout the state of Rhode Island $(R I)$ to in-person instruction from March 16, 2020 through to the beginning of the 2020/2021 school year. However, with the surge of virus infections in the fall of 2020 , most schools in RI continued to operate with fully remote or with hybrid inperson/on-line learning until January 2021. For younger children, daycare centers were also closed in March of 2020, but were allowed to reopen with reduced capacity in June, 2020. Restrictions on daycare capacity remained in effect until June 2021. Broader state-wide travel restrictions and stay-athome orders were enforced from March to May, 2020, with many businesses operating with reduced on-site work forces and/or work-from-home options until mid-2021. Indoor and outdoor mask policies were also in place throughout 2020 and 2021 following CDC guidance. Despite being one of the smaller US states with a population of just over 1 million, RI has suffered high numbers of SARS-CoV2 infections, with approximately 154,000 cases of COVID-19 illness and almost 3,000 deaths. RI has mirrored national trends with respect to disproportionate infections and deaths in Hispanic or Latino and Black or African American communities [10,11] as well as lower income families [12].

From 2009, Brown University and the Warren Alpert Medical School at Brown University has been home to a longitudinal study of child health and neurodevelopment, termed the RESONANCE study. Now part of the NIH Environmental influences on Child Health Outcomes (ECHO) program, the RESONANCE cohort consists of approximately 1600 caregiver-child dyads, who have been continuously 
medRxiv preprint doi: https://doi.org/10.1101/2021.08.10.21261846; this version posted August 11, 2021. The copyright holder for this preprint (which was not certified by peer review) is the author/funder, who has granted medRxiv a license to display the preprint in perpetuity. All rights reserved. No reuse allowed without permission.

enrolled between 0 and 5 years of age since 2009 and have been followed through infancy, childhood, and early adolescence. This cohort, therefore, offers a unique opportunity to explore the impact of the COVID-19 pandemic on child health trends in RI, which may reflect broader trends in the US.

In the absence of direct SARS-CoV-2 infection, environmental exposures associated with COVID-19 pandemic can affect the developing infant and child through multiple pathways. The human brain is unique in its prolonged developmental timeline [13, 14]. Infants are born with relatively immature brains that, like them, are simultaneously competent and vulnerable. Infants are inherently competent in their ability to initiate relationships, explore, seek meaning, and learn; but are vulnerable and depend entirely on caregivers for their survival, emotional security, modeling of behaviors, and the nature and rules of the physical and socio-cultural world that they inhabit [15]. The infant brain is likewise born with immense capacity to learn, remodel, and adapt, but is sensitive and vulnerable to neglect and environmental exposures that begin even before birth [16-18]. Optimal brain development depends on secure and trusting relationships with knowledgeable caregivers who are responsive to the infant's needs and interests. Neurodevelopmental processes, including myelination and synaptogenesis, for example, are stimulated by external cues and experiences like maternal interaction, and physical skinto-skin "kangaroo" care, touch, and warmth [19-22]. The brain's adaptive plasticity, however, is a double-edged sword. While positive and enriching environments can promote healthy brain development [23-27], neglect insecurity, stress, and lack of stimulation can impair maturing brain systems and disrupt cognitive and behavioral outcomes [28-30].

Maternal stress, anxiety, and depression in pregnancy can impact the developing fetal and infant brain structure and connectivity, leading to potential delays in motor, cognitive, and behavioral development $[31,32]$. It is believed that alterations in fetal exposure to stress-related hormones, including cortisol, affect theses changes in brain structure and function [33-35]. Past analysis has revealed strong associations between maternal prenatal stress and anxiety related to maternal or paternal displacement and job loss and infant health (birth weight and gestation duration), mortality, temperament, and cognitive development [36]. Throughout the COVID-19 pandemic, maternal and paternal job-loss, employment furloughs, or increased food / housing insecurity have been experienced by many families. Survey results at the beginning of the pandemic showed significantly increased rates of clinically relevant symptoms of maternal depression and anxiety [37].

Given these changes in children's home, education, and social environments, it is not surprising that cross-sectional and longitudinal studies of child and adolescent mental health throughout the current pandemic have revealed increased stress, anxiety, and depression [38]. Studies of child learning further show reduced academic growth in math and language arts in elementary and high school children [4]. The impact on infant and child cognitive development, however, remains less clear. Despite the 
medRxiv preprint doi: https://doi.org/10.1101/2021.08.10.21261846; this version posted August 11, 2021. The copyright holder for this preprint (which was not certified by peer review) is the author/funder, who has granted medRxiv a license to display the preprint in perpetuity.

All rights reserved. No reuse allowed without permission.

known impact of parent and family stress, economic adversity, reduced parent and peer interaction and other stimulating environments, on child brain development [9], direct observation of reduced development as a result of the COVID-19 pandemic remains elusive, despite early findings of altered temperament in 3month old infants [39].

In this work, therefore, we specifically sought to explore individual and population-level trends in infant and early child neurodevelopment. Analyses of cognitive development, assessed using Mullen Scales of Early Learning [40], a population normed and clinically administered tool that assesses function across the five primary domains of fine and gross motor control, visual reception, and expressive and respective language via direct observation and performance, provides some of the first direct evidence of the developmental impact of the COVID-19 pandemic. Comparing yearly mean scores since 2011, controlling for age, gender, demographic, and socioeconomic indicators, we find striking evidence of declining overall cognitive functioning in children beginning in 2020 and continuing through 2021. We find that males appear significantly more impacted than females, and that higher socioeconomic status (SES, as measured by maternal education [41]) helps buffer against this negative impact. On a more individual level, we examined longitudinal pre and during-pandemic trends in the same children from 2018 to 2021, again finding declines in ability in 2020 and 2021.

Finally, to examine the impact of the pandemic during pregnancy on subsequent child development, we compared developmental scores in children up to 1 year of age born prior to 2019 and after July 2020 (i.e., those born prior to the pandemic and those whose in utero development may have been impacted by the COVID-19 environment for at least the last trimester of pregnancy). Again, we find significantly reduced scores in children born since the start of the pandemic, with lower SES individuals and males more significantly affected. Throughout all analyses, however, we found that the perceived stress of mothers in our cohort was unchanged throughout the pandemic, and was not significantly associated with developmental scores.

These results provide compelling early evidence of the impact of the COVID-19 pandemic, even in the absence of direct SARS-CoV-2 infection, on infant and early child neurodevelopment. 
medRxiv preprint doi: https://doi.org/10.1101/2021.08.10.21261846; this version posted August 11, 2021. The copyright holder for this preprint (which was not certified by peer review) is the author/funder, who has granted medRxiv a license to display the preprint in perpetuity.

All rights reserved. No reuse allowed without permission.

\section{METHODS}

All data were acquired in accordance with ethical approval and oversight by the Rhode Island Hospital institutional review board, with informed consent obtained from all parents or legal guardians.

Since 2011, 1224 cognitive assessments were collected from 672 healthy, full-term, and neurotypically-developing children between 3 months to 3 years of age. Repeated measures were separated by at least 1 year (mean $=384+/-41$ days). A general overview of all child assessment timings are shown in Figure 1a. This dataset included 1070 assessments (from 605 children) prior to March 2020; 154 assessments (from 118 children) between March 2020 and June 2021; with 39 children who were born just prior to the pandemic in 2018 and 2019, and following during the pandemic to 2021.

To start, we grouped measures by testing year from 2011 to 2021 and performed an analysis of covariance to compare the three primary composite measures: the early learning composite (ELC), verbal development quotient (VDQ) and non-verbal development quotient (NVDQ) between each pre and during pandemic year-pair; with child age, and maternal education (as a proxy for socioeconomic status, SES) as covariates.

To investigate the cognitive trends more rigorously, we next constructed a series of general linear mixed-effects models that modeled the cognitive measures while taking a step-wise approach to include additional predictive factors, beginning with

$C M_{i, j}=\beta_{0, j}+\beta_{1, j} \times a g e_{i, j}+\beta_{2, j} C O V I D_{\text {model }}$

Where CM is the cognitive measure of interest (ELC, VDQ, or NVDQ) of child $j$ at time-point $i . \beta_{0, j}$ is the intercept and $\beta_{1, j} \ldots, \beta_{n, j}$, are the regression coefficients. $\beta_{0, j}, \beta_{1, j}$ combine a sample fixed effect and a subject-specific random effect $\left(u_{j}\right)$, e.g.,

$\beta_{0, j}=\beta_{0}+\mu_{0, j}$

and

$\beta_{1, j}=\beta_{1}+\mu_{1, j}$

allow individual differences in mean cognitive function and change with age. The COVID model term is a binary factor that is 0 for any testing date prior to March 2020, and 1 for testing dates thereafter. Equation [1] was fit to the complete cohort dataset using the fitlme function in Matlab (MathWorks, Cam- 
medRxiv preprint doi: https://doi.org/10.1101/2021.08.10.21261846; this version posted August 11, 2021. The copyright holder for this preprint (which was not certified by peer review) is the author/funder, who has granted medRxiv a license to display the preprint in perpetuity.

All rights reserved. No reuse allowed without permission.

bridge, MA v2019b). The COVID model term allowed us to test the hypothesis that pandemic-related environmental changes are associate with a significant negative change in cognitive functioning.

Building from our simple function, we used a step-wise regression approach to systematically include additional factors and interactive terms in our general model, i.e.,:

$$
\begin{aligned}
& C M_{i, j}=\beta_{0, j}+\beta_{1, j} \times a g e_{i, j}+\beta_{2, j} \text { COVID }_{\text {model }}+\beta_{3, j} S E S, \\
& C M_{i, j}=\beta_{0, j}+\beta_{1, j} \times a g e_{i, j}+\beta_{2, j} \text { COVID }_{\text {model }}+\beta_{3, j} S E S+\beta_{4, j} \text { Gender }_{j}
\end{aligned}
$$

to control for potential differences in gender and socioeconomic factors in the population. Given past findings associating COVID-19 stay-at-home orders and prematurity or potential low birth weight [42], we further included these birth outcomes as additional predictors,

$C M_{i, j}=\beta_{0, j}+\beta_{1, j} \times a g e_{i, j}+\beta_{2, j} \operatorname{COVID}_{\text {model }}+\beta_{3, j} S E S+\beta_{4, j}$ Gender $_{j}+\beta_{5, j}$ Birthweight $+\beta_{6, j}$ Gestation

Finally, we also tested the interaction between the COVIDmodel and SES and Gender terms to test whether these factors had additive or buffering effects,

$C M_{i, j}=\beta_{0, j}+\beta_{1, j} \times a g e_{i, j}+\beta_{2, j} \operatorname{COVID}_{\text {model }}+\beta_{3, j} S E S \times$ COVID $_{\text {model }}+\beta_{4, j}$ Gender $_{j} \times$ COVID $_{\text {model }}$

At each stage of analysis, we examined the parsimonious fit of the model using the Bayesian Information Criterion (BIC) [43], stopping when additional factors no longer improved the model fit. In the final model, we then examined the significance level of each model parameter, specifically the COVID model term, which denotes a potential significant difference in pre- and during pandemic scores.

Recognizing that the analysis from 2011 to 2021 contained differing sets of children we next reduced our dataset to 39 children who were enrolled up to a year prior to the pandemic and who had at least 1 visit before and 1 visit during the pandemic (Table 1, Figure 1b). To this reduced set of data, we performed analogous mixed-effects modeling using the series of general linear models constructed above (Eqns. 1 to 5).

Given the potential impact of the pandemic on maternal stress and, consequently, the developing fetal brain, we next compared the cognitive measures in 291 children under 1 year of age who were born 
medRxiv preprint doi: https://doi.org/10.1101/2021.08.10.21261846; this version posted August 11, 2021. The copyright holder for this preprint (which was not certified by peer review) is the author/funder, who has granted medRxiv a license to display the preprint in perpetuity.

All rights reserved. No reuse allowed without permission.

before January 2019 (i.e., their prenatal and first postnatal year of development occurred before the pandemic) to 118 children born after July 2020 (i.e., at least one term of pregnancy and the first postnatal year occurred during the pandemic) (Table 1, Figure 1c). As above, we used a mixed-effects approach to model our series of general linear models (Eqns. 1 to 5).

To test whether maternal stress was a potential causative factor, we replaced the Model term in our general linear models with the total score from the perceived stress scale (PSS) [44], a 10-item selfreport that provides a continuous scale of perceived and experienced stress due to life situations.

$$
C M_{i, j}=\beta_{0, j}+\beta_{1, j} \times a g e_{i, j}+\beta_{2, j} P S S+\beta_{3, j} S E S \times P S S+\beta_{4, j} \text { Gender }_{j} \times P S S
$$

PSS scores were obtained from each pregnant mother prior to birth and at each child visit starting in 2017. We performed this analysis twice. In the first set, we used the post-natal scores collected at the same time as the child cognitive measures, in the second, we used the prenatal PSS scores obtained from the mother during pregnancy. 
medRxiv preprint doi: https://doi.org/10.1101/2021.08.10.21261846; this version posted August 11, 2021. The copyright holder for this preprint (which was not certified by peer review) is the author/funder, who has granted medRxiv a license to display the preprint in perpetuity. All rights reserved. No reuse allowed without permission.

\section{RESULTS}

Demographic summaries of the children included in each set of analysis (complete set; children followed pre- and during pandemic; and children under 1 year of age born before and during the pandemic) are shown in Table 1.

Results from our ANCOVA comparing each year pre- and during-pandemic year pair is shown in Table 2. In general, we find mean ELC values from 2011 to 2019 ranging from 98.5 to 107.3, with standard deviations of 15.2 to 19.7 (Fig. 2), in general agreement with the expected mean of 100 and standard deviation of 15. Means and standard deviations for 2020 (March to December) and 2021 (January through Aug) were: $86.3+/-17.9$ and 78.9+/-21.6, respectively. Controlling for differences in age and maternal education, we find inconsistent differences in mean ELC between 2011-2019 and 2020, but consistent and significant reductions between 2011-2019 and 2021 ( $p<0.001)$. Results are similar for the verbal and non-verbal composite measures (Fig. 2, Table 2). In all cases maternal education was a significant and positive factor on ELC, VDQ, and NVDQ measures.

Results from our mixed model analysis using our complete data set are summarized in Table $\mathbf{3}$ and reinforce the results obtained from our initial ANCOVA. For each composite score, the model including child age, maternal education, child gender, birth weight, gestation duration, and test timing (pre vs. during the pandemic)), as well as interaction terms of timing, gender, and maternal education was the most parsimonious model (lowest BIC). Across all measures, we found cognitive scores were significantly reduced during the pandemic by 27 to 37 points (or almost two full standard deviations), $p$ values $<0.01$, with higher maternal education, increased birth weight and increased gestation duration being protective; while males were more heavily affected. We did not find significant differences in birth weight or gestation duration overall in the pre vs during pandemic children ( $p>0.3)$, Fig. 3.

Repeating this set of analysis in the subset of 39 children who were born immediately before the beginning of the pandemic and whom we have followed up over the past 18 months (Table 4) presents contrasting results. Longitudinal plots of individual cognitive measures are shown in Fig. 4. Across all composite cognitive measures, we find that the inclusion of a term that distinguishes between pre vs. during the COVID-19 pandemic does not improve the model fit, and no significant decrease in cognitive measures in these children. This result suggests that much of the reductions observed in Figure 2, and Tables 2 and $\mathbf{3}$ may be driven by the infants born during the pandemic. Results from our last set of analysis (Table 5), restricted to newborns and infants under 1 year of age born before or during the pandemic, support this hypothesis. Here we find a significant decrease in child cognitive scores in children born during the pandemic with males affected more than females, and higher maternal education being a protective factor. 
medRxiv preprint doi: https://doi.org/10.1101/2021.08.10.21261846; this version posted August 11, 2021. The copyright holder for this preprint (which was not certified by peer review) is the author/funder, who has granted medRxiv a license to display the preprint in perpetuity.

All rights reserved. No reuse allowed without permission.

The strong effect of the pandemic on early neurodevelopment suggests that maternal stress, already shown to be increased in mothers at the start of the pandemic may be an important factor. However, including maternal stress, recorded both prenatally and following delivery into our model, in place of the Model term was not significant (Table 6). Indeed, when examining perceived stress in mothers by year we find (Fig. 5) no significant increase or decrease during the pandemic compared to prepandemic years. 
medRxiv preprint doi: https://doi.org/10.1101/2021.08.10.21261846; this version posted August 11, 2021. The copyright holder for this preprint (which was not certified by peer review) is the author/funder, who has granted medRxiv a license to display the preprint in perpetuity. All rights reserved. No reuse allowed without permission.

\section{DISCUSSION}

Children are inherently shaped by their environment. Across the fetal, infant, and early childhood lifestages, a child's brain undergoes immense structural and functional growth that is driven by an integrative mixture of genetic and environmental factors. The outbreak of the COVID-19 pandemic, and the associated economic shut-down, school disruptions, and social distancing, stay-at-home, and mask policies have fundamentally altered the environment in which children and pregnant individuals have lived, over the past 18 months. Despite much speculation, the short and long-term impacts of the COVID-19 pandemic on fetal and child health and neurodevelopment in the absence of direct infection are not yet known [45]. This gap makes it difficult to develop evidence-based guidelines of care for expectant mothers and individuals, design effective strategies for follow-up care of sensitive infants; or provide informed guidance for school and daycare reopening and in-person vs. online learning.

Leveraging data collected continuously over the past decade in Providence, RI and surrounding areas, we sought to investigate how the pandemic has impacted cognitive development and function in newborns and young children. Included pregnant individuals and children reported no symptoms of SARSCoV-2 infection or had evidence of positive antibody or RT-PCR testing. Families also reported having adhered to stay-at-home and on-going mask and social distancing policies, suggesting observed effects are environmentally driven rather than due to potential direct effects of infection. However, we did not perform antibody testing to confirm past infection status.

Overall, we find that measured verbal, non-verbal, and overall cognitive scores are significantly lower since the beginning of the pandemic. Looking further, we find that children born before the pandemic and followed through the initial stages do not show a reduction in skills or performance, but rather that young infants born since the beginning of the pandemic show significantly lower performance than infants born before January 2019. Thus, our results seem to suggest that early development is impaired by the environmental conditions brought on by the pandemic.

In contrast to other on-going studies through the pandemic [37, 39], we did not find an increase in general maternal stress and, thus, this was not a significant predictor factor in our analysis. This may reflect a general insensitivity of the PSS tool used here to pandemic-related stress; the potential selection bias in the families included in our study; or strong family and social support networks available to the pregnant individuals. The PSS is a standardized ten-item questionnaire that asks about general life stressors and how stressful individuals find their lives but does not include specific questions related to health or wellbeing. In contrast, the MOM-COPE study utilized retrospective data collection using an ad-hoc developed questionnaire focused on worry and anxiety of COVID-19 infection, pregnancy risk, and their own and their infant's health [39]. The survey-based study by Lebel and colleagues [37] also used a specially developed questionnaire to gauge maternal concern of the pandemic and its im- 
medRxiv preprint doi: https://doi.org/10.1101/2021.08.10.21261846; this version posted August 11, 2021. The copyright holder for this preprint (which was not certified by peer review) is the author/funder, who has granted medRxiv a license to display the preprint in perpetuity. All rights reserved. No reuse allowed without permission.

pact on their own and their infant's health. Additional measures of depression and anxiety were assessed using the standardized Edinburgh Depression Scale (EDS [46]) and PROMIS Anxiety Adult 7item short form [47] instruments.

With respect to included participants, families in our study were drawn from the local Providence and surrounding communities with focus on typical child development. Exclusion criteria for enrollment has been consistent across the duration of the study and includes: twin or multiple pregnancy; preterm birth prior to 37 weeks; small for gestational age and/or birthweight less and 1500g; 5min APGAR scores <= 8; major psychiatric illness in the mother, including depression requiring medication within 6 months of pregnancy; use of alcohol, tobacco, or illicit substances during pregnancy; diagnosed neurological disorder (e.g., epilepsy) in the child. During the pandemic, we did not target individuals with COVID-19 exposure or illness. However, since all study visits take place in a clinical setting, parents less concerned about the pandemic, and those with strong social support networks, may have been more likely to participate than those with greater concerns. Thus, our observation that maternal stress (PSS) did not significantly increase may simply reflect the reality that we only tested less stressed and anxious mothers. These parents may also have greater financial security or other socioeconomic characteristics. However, in ad hoc analysis of maternal education measures of our full cohort by year, we did not observe a significant difference in maternal education between families tested before or during the pandemic (Fig. 5b). This, however, is an area requiring further investigation.

Family and social support is also an important contributor to maternal health and wellbeing [48] that can also affect infant temperament, behavior, and cognitive development [49]. Building from our discussion of maternal stress, we unfortunately did not collect additional measures related to daycare or working from home status of our parents. It is possible that parents of lower socioeconomic means may have been less able to afford daycare or prolonged parental leave. These are additional areas of focus, which could provide important guides for public health policies.

The first 1,000 days of a child's life are commonly cited as an important and sensitive period of child development. Environmental factors, including maternal mental and physical health, nutrition, stimulation, and supportive caregiving can individually and in combination affect the developing fetal and infant brain throughout this early life period [19-22]. Many of these factors have been substantively impacted by public health policies enacted in response to the SARS-CoV-2 outbreak. Work-from-home and shelter-in-place orders, for example, along with closed daycares, nurseries, and preschools may have dramatically changed the quantity and quality of parent, caregiver, and teach-child interaction and stimulation. Studies in older children and adolescents over the past year have found reduced social interaction, increased media consumption, and reduced physical activity [50-52]. It is likely these same trends are true for younger children and infants as well with the closure or reduced capacity of 
medRxiv preprint doi: https://doi.org/10.1101/2021.08.10.21261846; this version posted August 11, 2021. The copyright holder for this preprint (which was not certified by peer review) is the author/funder, who has granted medRxiv a license to display the preprint in perpetuity.

All rights reserved. No reuse allowed without permission.

daycares and preschools, and may be associated with impaired motor development, motor coordination and visual processing, language development, and socioemotional processing. In addition, masks worn in public settings and in school or daycare settings may impact a range of early developing skills, such as attachment, facial processing, and socioemotional processing.

Unfortunately, we do not have direct or parent-reported measures indicative of parent or caregiverchild interaction, early media exposure, or physical activity to investigate the potential causative role of these factors.

One aspect also not investigated here is the impact of mask-wearing by the study staff during child visits and assessments [53]. The inability of infants to see full facial expressions may have eliminated non-verbal cues, muffled instructions, or otherwise altered the understanding of the test questions and instructions.

For parents who were able to work from home, and did not face furlough or employment loss, the dual role of childcare and work has increased the strain on parents, in particular mothers, resulting in increased parental stress and anxiety. For families who have suffered job loss, they may experience greater stress, depression, anxiety, as well as food and housing insecurity. Although we found no significant changes in the degree of maternal perceived stress, and we did, however, find that maternal education, often used as a marker of surrogate of socioeconomic status, was generally associated with improved cognitive function and, as an interactive term, had a buffering effect against the impact of the pandemic. This is particularly salient given the disproportionate effect the pandemic has had on lower income families [54], who have not only dealt with job loss and financial insecurity, but are also over-represented in front line and essential service employment with increased risk of SARS-CoV-2 infection and COVID-19 illness [55].

What is unclear from our data, however, is if observed declines or impairments are temporary and will normalize as employment and school closures are lifted and children return to pre-pandemic levels of play and interaction, and family financial insecurity and mental health challenges subside. Unfortunately, when that will occur is also unknown given the ongoing surge of infections associated with new virus variants. It is clear, however, that young infants and children are developing differently than prepandemic, and that addressing this now while their brain is at its most plastic and responsive, is imperative. Programs such as unemployment insurance, Supplemental Nutrition Assistance Program (SNAP), the Special Supplemental Nutrition Program for Women, Infants, and Children (WIC), and housing assistance, may help minimize the impact of the pandemic on the most sensitive of children. In addition, further research directly exploring aspects of parent-child attachment, interaction, nutrition, 
medRxiv preprint doi: https://doi.org/10.1101/2021.08.10.21261846; this version posted August 11, 2021. The copyright holder for this preprint (which was not certified by peer review) is the author/funder, who has granted medRxiv a license to display the preprint in perpetuity.

All rights reserved. No reuse allowed without permission.

food security, and environmental stimulation is needed to understand the primary driving factors underlying the trends presented here. 
medRxiv preprint doi: https://doi.org/10.1101/2021.08.10.21261846; this version posted August 11, 2021. The copyright holder for this preprint (which was not certified by peer review) is the author/funder, who has granted medRxiv a license to display the preprint in perpetuity.

All rights reserved. No reuse allowed without permission.

\section{CONCLUSION}

The COVID-19 pandemic has fundamentally altered the child health landscape, with pregnant mothers and individuals, and children living in a strikingly different economic, psychosocial, and educational environment than what was present just 18 months ago. Against this environmental backdrop, unanswered questions remain regarding the impact of the work-from-home, shelter-in-place, and other public health policies that have limited social interaction and typical childhood experiences on early child neurodevelopment. In this work, we provide early evidence suggestive of significant reductions in attained cognitive function and performance in children born over the past 18 months during the pandemic. While socioeconomic factors appear to mitigate against the negative consequences of the pandemic, the primary factors underlying our observed trends remain unknown. Understanding these factors are critical to helping ensure affected children rebound as the pandemic winds down and they re-enter daycares and schools; as well as implementing additional public health and educational policies that address the most affected of children, particularity those in lower income families. 
medRxiv preprint doi: https://doi.org/10.1101/2021.08.10.21261846; this version posted August 11, 2021. The copyright holder for this preprint (which was not certified by peer review) is the author/funder, who has granted medRxiv a license to display the preprint in perpetuity.

All rights reserved. No reuse allowed without permission.

\section{DATA SHARING}

All data acquired and presented here is freely available upon request to the authors.

\section{ROLE OF THE FUNDING SOURCE}

Funding for this study was provided by the National Institutes of Health (SCD). Neither funder played any role in the acquisition, analysis or interpretation of the data, or were involved in the drafting or approval of this manuscript.

\section{CONTRIBUTOR ROLES}

All listed authors were involved in the study design, data acquisition and analysis, drafting and revising this manuscript, and provide final and accountable approval for its contents. SCD and DV verify the underlying data.

\section{FINANCIAL DISCLOSURES}

The authors report no significant financial conflicts of interest with respect to the subject matter of this manuscript. 
medRxiv preprint doi: https://doi.org/10.1101/2021.08.10.21261846; this version posted August 11, 2021. The copyright holder for this preprint (which was not certified by peer review) is the author/funder, who has granted medRxiv a license to display the preprint in perpetuity.

All rights reserved. No reuse allowed without permission.

Tables \& Figures 
medRxiv preprint doi: https://doi.org/10.1101/2021.08.10.21261846; this version posted August 11, 2021. The copyright holder for this preprint (which was not certified by peer review) is the author/funder, who has granted medRxiv a license to display the preprint in perpetuity.

All rights reserved. No reuse allowed without permission.

Table 1. Group demographics for each child cohort, including the complete set of data tested over the past decade; children born just before the pandemic and followed during the pandemic; and children under 1 year of age born before January 2019 or after July 2020.

\begin{tabular}{|c|c|c|c|c|}
\hline & & Complete Set & $\begin{array}{l}\text { Matched Pre \& } \\
\text { During }\end{array}$ & Under 1 Year \\
\hline \multirow{2}{*}{ Biological Sex } & Male & 292 & 17 & 186 \\
\hline & Female & 381 & 22 & 223 \\
\hline \multirow{2}{*}{ Race } & Hispanic & 112 & 9 & 70 \\
\hline & Not Hispanic & 561 & 30 & 339 \\
\hline \multirow{5}{*}{ Ethnicity } & Caucasian / White & 320 & 29 & 248 \\
\hline & African American / Black & 43 & 2 & 28 \\
\hline & Asian & 8 & 0 & 6 \\
\hline & Mixed Race & 111 & 5 & 76 \\
\hline & Unknown / Declined & 191 & 3 & 51 \\
\hline \multirow{7}{*}{$\begin{array}{r}\text { Maternal Educa- } \\
\text { tion }\end{array}$} & Some Primary School & 0 & 0 & 0 \\
\hline & Primary School Graduate & 0 & 0 & 0 \\
\hline & Some High School & 20 & 2 & 10 \\
\hline & High School Graduate & 91 & 7 & 66 \\
\hline & Some College & 157 & 13 & 104 \\
\hline & College Graduate & 143 & 8 & 82 \\
\hline & Graduate & 262 & 9 & 147 \\
\hline \multirow{2}{*}{ Birth Outcomes } & Birth Weight (lbs) & $7.3(1.3)$ & $7.36(1)$ & $7.3(1.3)$ \\
\hline & Gestation (weeks) & $38(3.7)$ & $38(1.7)$ & $39(2)$ \\
\hline
\end{tabular}


medRxiv preprint doi: https://doi.org/10.1101/2021.08.10.21261846; this version posted August 11, 2021. The copyright holder for this preprint (which was not certified by peer review) is the author/funder, who has granted medRxiv a license to display the preprint in perpetuity.

All rights reserved. No reuse allowed without permission.

Table 2. Year-pair comparisons of mean ELC, VDQ, and NVDW composite scores measured before and during the COVID-19 pandemic. While we see inconsistent differences between each prepandemic year and 2020, we find consistent statistically significant reductions between each prepandemic year and 2021, controlling for child age and maternal education.

\begin{tabular}{|c|c|c|c|c|c|c|c|c|}
\hline \multicolumn{3}{|c|}{ ELC } & \multicolumn{3}{|c|}{ VDQ } & \multicolumn{3}{|c|}{ NVDQ } \\
\hline & 2020 & 2021 & & 2020 & 2021 & & 2020 & 2021 \\
\hline 2011 & 0.023 & $<0.0001$ & 2011 & 0.045 & $<0.0001$ & 2011 & 0.029 & $<0.0001$ \\
\hline 2012 & 0.79 & $<0.0001$ & 2012 & 0.97 & $<0.0001$ & 2012 & 0.92 & $<0.0001$ \\
\hline 2013 & $<0.0001$ & $<0.0001$ & 2013 & $<0.0001$ & $<0.0001$ & 2013 & 0.007 & $<0.0001$ \\
\hline 2014 & $<0.0001$ & $<0.0001$ & 2014 & $<0.0001$ & $<0.0001$ & 2014 & $<0.0001$ & $<0.0001$ \\
\hline 2015 & $<0.0001$ & $<0.0001$ & 2015 & 0.0004 & $<0.0001$ & 2015 & 0.0006 & $<0.0001$ \\
\hline 2016 & 0.0001 & $<0.0001$ & 2016 & 0.14 & $<0.0001$ & 2016 & $<0.0001$ & $<0.0001$ \\
\hline 2017 & 0.015 & $<0.0001$ & 2017 & 0.042 & $<0.0001$ & 2017 & 0.16 & $<0.0001$ \\
\hline 2018 & 0.12 & $<0.0001$ & 2018 & 0.11 & $<0.0001$ & 2018 & 0.35 & $<0.0001$ \\
\hline 2019 & 0.002 & $<0.0001$ & 2019 & 0.008 & $<0.0001$ & 2019 & 0.04 & $<0.0001$ \\
\hline
\end{tabular}


medRxiv preprint doi: https://doi.org/10.1101/2021.08.10.21261846; this version posted August 11, 2021. The copyright holder for this preprint (which was not certified by peer review) is the author/funder, who has granted medRxiv a license to display the preprint in perpetuity. All rights reserved. No reuse allowed without permission.

Table 3. Results of our sequential or step-wise general linear models investigating differences in pre vs. during-pandemic composite ELC, VDQ, and NVDQ measures. The COVID-model term is 0 for all test dates prior to March 2020, and 1 for all dates following, allowing us to test for a signifiant change in pre vs. during-pandemic scores. Across all models, we find this term is significant $(p<0.01)$. We also note that males appear more heavily affected that females, but that higher maternal education appears to be protective against the effects of the pandemic.

\begin{tabular}{|c|c|c|c|c|c|c|c|c|c|c|}
\hline \multirow{2}{*}{$\begin{array}{c}\text { ELC } \\
\text { BIC } \\
\text { Term }\end{array}$} & \multicolumn{2}{|c|}{$\begin{array}{r}\text { Model } 1 \\
10288.062846\end{array}$} & \multicolumn{2}{|c|}{$\begin{array}{r}\text { Model } 2 \\
9321.271505\end{array}$} & \multicolumn{2}{|c|}{$\begin{array}{r}\text { Model } 3 \\
9305.278285\end{array}$} & \multicolumn{2}{|c|}{$\begin{array}{r}\text { Model } 4 \\
8469.120136\end{array}$} & \multicolumn{2}{|c|}{$\begin{array}{r}\text { Model } 5 \\
\text { 8461.154085 }\end{array}$} \\
\hline & Estimate & pValue & Estimate & pValue & Estimate & pValue & Estimate & pValue & Estimate & pValue \\
\hline Intercept & $\begin{array}{l}95.27373 \\
2\end{array}$ & 0.000000 & $\begin{array}{l}77.15468 \\
5\end{array}$ & 0.000000 & $\begin{array}{l}79.75920 \\
5\end{array}$ & 0.000000 & 5.697486 & 0.635849 & 7.342544 & 0.540383 \\
\hline Child Age & 0.004234 & 0.002910 & 0.004015 & 0.005853 & 0.004240 & 0.003387 & 0.004745 & 0.001152 & 0.004722 & 0.001149 \\
\hline COVID-Model & $\begin{array}{l}- \\
12.10102 \\
5\end{array}$ & 0.000000 & $\begin{array}{l}- \\
11.99400 \\
3\end{array}$ & 0.000000 & $\begin{array}{l}- \\
12.03450 \\
1\end{array}$ & 0.000000 & $\begin{array}{l}- \\
12.56996 \\
4\end{array}$ & 0.000000 & $\begin{array}{l}- \\
31.70724 \\
2\end{array}$ & 0.000091 \\
\hline Maternal Ed. & & & 3.375311 & 0.000000 & 3.376083 & 0.000000 & 3.062195 & 0.000000 & 2.553374 & 0.000000 \\
\hline Male & & & & & -4.795305 & 0.000020 & -4.218355 & 0.000122 & -3.629912 & 0.001307 \\
\hline Gestation & & & & & & & 1.644557 & 0.000005 & 1.670624 & 0.000004 \\
\hline Birth Weight & & & & & & & 1.618325 & 0.003349 & 1.608542 & 0.003496 \\
\hline Male x Model & & & & & & & & & -5.210031 & 0.118383 \\
\hline $\begin{array}{l}\text { Maternal Ed. x } \\
\text { Model }\end{array}$ & & & & & & & & & 4.089579 & 0.003280 \\
\hline VDO & \multicolumn{2}{|c|}{ Model 1} & \multicolumn{2}{|c|}{ Model 2} & \multicolumn{2}{|c|}{ Model 3} & \multicolumn{2}{|c|}{ Model 4} & \multicolumn{2}{|c|}{ Model 5} \\
\hline BIC & \multicolumn{2}{|c|}{11252.715679} & \multicolumn{2}{|c|}{10190.924489} & \multicolumn{2}{|c|}{10179.861822} & \multicolumn{2}{|c|}{9299.916193} & \multicolumn{2}{|c|}{9299.341288} \\
\hline Term & Estimate & pValue & Estimate & pValue & Estimate & pValue & Estimate & pValue & Estimate & pValue \\
\hline Intercept & $\begin{array}{r}93.53301 \\
0\end{array}$ & 0.000000 & $\begin{array}{r}66.89222 \\
9\end{array}$ & 0.000000 & $\begin{array}{r}69.93796 \\
3\end{array}$ & 0.000000 & 3.376040 & 0.844570 & 4.581158 & 0.790121 \\
\hline Child Age & 0.007594 & 0.000044 & 0.005348 & 0.004688 & 0.005635 & 0.002886 & 0.005894 & 0.002397 & 0.005890 & 0.002391 \\
\hline COVID-Model & $\begin{array}{r}- \\
20.12408 \\
6\end{array}$ & 0.000000 & $\begin{array}{r}- \\
19.70636 \\
5\end{array}$ & 0.000000 & $\begin{array}{r}- \\
19.74255 \\
3\end{array}$ & 0.000000 & $\begin{array}{r}- \\
19.45135 \\
4\end{array}$ & 0.000000 & $\begin{array}{r}- \\
37.34855 \\
2\end{array}$ & 0.001706 \\
\hline Maternal Ed. & & & 5.109479 & 0.000000 & 5.105734 & 0.000000 & 4.503137 & 0.000000 & 4.038469 & 0.000000 \\
\hline Male & & & & & -5.633027 & 0.000276 & -5.549127 & 0.000455 & -4.986241 & 0.002484 \\
\hline Gestation & & & & & & & 1.408398 & 0.005929 & 1.440316 & 0.005010 \\
\hline Birth Weight & & & & & & & 2.083655 & 0.008176 & 2.072341 & 0.008587 \\
\hline Male x Model & & & & & & & & & -4.726815 & 0.338660 \\
\hline
\end{tabular}


medRxiv preprint doi: https://doi.org/10.1101/2021.08.10.21261846; this version posted August 11, 2021. The copyright holder for this preprint (which was not certified by peer review) is the author/funder, who has granted medRxiv a license to display the preprint in perpetuity.

All rights reserved. No reuse allowed without permission.

\begin{tabular}{|c|c|c|c|c|c|c|c|c|c|c|}
\hline \multirow{2}{*}{$\begin{array}{c}\text { ELC } \\
\text { BIC } \\
\text { Term }\end{array}$} & \multicolumn{2}{|c|}{$\begin{array}{r}\text { Model } 1 \\
10288.062846\end{array}$} & \multicolumn{2}{|c|}{$\begin{array}{r}\text { Model } 2 \\
9321.271505\end{array}$} & \multicolumn{2}{|c|}{$\begin{array}{r}\text { Model } 3 \\
9305.278285\end{array}$} & \multicolumn{2}{|c|}{$\begin{array}{r}\text { Model } 4 \\
8469.120136\end{array}$} & \multicolumn{2}{|c|}{$\begin{array}{r}\text { Model } 5 \\
\text { 8461.154085 }\end{array}$} \\
\hline & Estimate & pValue & Estimate & pValue & Estimate & pValue & Estimate & pValue & Estimate & pValue \\
\hline $\begin{array}{l}\text { Maternal Ed. x } \\
\text { Model }\end{array}$ & & & & & & & & & 3.775018 & 0.065723 \\
\hline & & & & & & & & & & \\
\hline
\end{tabular}


medRxiv preprint doi: https://doi.org/10.1101/2021.08.10.21261846; this version posted August 11, 2021. The copyright holder for this preprint (which was not certified by peer review) is the author/funder, who has granted medRxiv a license to display the preprint in perpetuity.

All rights reserved. No reuse allowed without permission.

\begin{tabular}{|c|c|c|c|c|c|c|c|c|c|c|}
\hline \multirow{2}{*}{$\begin{array}{c}\text { NVDQ } \\
\text { BIC } \\
\text { Term }\end{array}$} & \multicolumn{2}{|c|}{$\begin{array}{l}\text { Model } 1 \\
11011.785624\end{array}$} & \multicolumn{2}{|c|}{$\begin{array}{l}\text { Model } 2 \\
\quad 9960.852998\end{array}$} & \multicolumn{2}{|c|}{$\begin{array}{l}\text { Model } 3 \\
\qquad 9950.889997\end{array}$} & \multicolumn{2}{|c|}{$\begin{array}{l}\text { Model } 4 \\
\quad 9037.219460\end{array}$} & \multicolumn{2}{|c|}{$\begin{array}{l}\text { Model } 5 \\
\text { 9036.929494 }\end{array}$} \\
\hline & Estimate & pValue & Estimate & pValue & Estimate & pValue & Estimate & pValue & Estimate & pValue \\
\hline Intercept & $\begin{array}{r}108.5042 \\
97\end{array}$ & 0.000000 & $\begin{array}{r}81.26229 \\
8\end{array}$ & 0.000000 & $\begin{array}{r}84.14567 \\
1\end{array}$ & 0.000000 & 8.099286 & 0.600946 & 9.080857 & 0.558075 \\
\hline Child Age & -0.004783 & 0.005940 & -0.007278 & 0.000047 & -0.007061 & 0.000072 & -0.008527 & 0.000002 & -0.008541 & 0.000002 \\
\hline COVID-Model & $\begin{array}{r}- \\
15.30586 \\
5\end{array}$ & 0.000000 & $\begin{array}{r}- \\
14.71208 \\
9\end{array}$ & 0.000000 & $\begin{array}{r}- \\
14.70860 \\
6\end{array}$ & 0.000000 & $\begin{array}{r}- \\
14.67272 \\
4\end{array}$ & 0.000000 & $\begin{array}{r}- \\
27.07196 \\
1\end{array}$ & 0.009252 \\
\hline Maternal Ed. & & & 5.149235 & 0.000000 & 5.117169 & 0.000000 & 4.791398 & 0.000000 & 4.425289 & 0.000000 \\
\hline Male & & & & & -4.982514 & 0.000539 & -4.711620 & 0.000963 & -4.120723 & 0.005689 \\
\hline Gestation & & & & & & & 1.743029 & 0.000149 & 1.764651 & 0.000133 \\
\hline Birth Weight & & & & & & & 1.568929 & 0.026826 & 1.566894 & 0.027418 \\
\hline Male x Model & & & & & & & & & -5.459957 & 0.207356 \\
\hline $\begin{array}{l}\text { Maternal Ed. x } \\
\text { Model }\end{array}$ & & & & & & & & & 2.836307 & 0.116332 \\
\hline
\end{tabular}


medRxiv preprint doi: https://doi.org/10.1101/2021.08.10.21261846; this version posted August 11, 2021. The copyright holder for this preprint (which was not certified by peer review) is the author/funder, who has granted medRxiv a license to display the preprint in perpetuity. All rights reserved. No reuse allowed without permission.

Table 4. Results of our step-wise general linear models investigating the impact of the pandemic on longitudinal cognitive development in children born up to a year prior to the pandemic. Overall, we note no significant reductions in development trends. However, given the same sample size $(\mathrm{n}=39)$ care should be taken when interpreting these results.

\begin{tabular}{|c|c|c|c|c|c|c|c|c|c|c|}
\hline ELC & \multicolumn{2}{|c|}{ Model 1} & \multicolumn{2}{|c|}{ Model 2} & \multicolumn{2}{|c|}{ Model 3} & \multicolumn{2}{|c|}{ Model 4} & \multicolumn{2}{|c|}{ Model 5} \\
\hline BIC & \multicolumn{2}{|c|}{1102.12489} & \multicolumn{2}{|c|}{1101.898327} & \multicolumn{2}{|c|}{1101.612437} & \multicolumn{2}{|c|}{951.013815} & \multicolumn{2}{|c|}{953.514413} \\
\hline Term & Estimate & pValue & Estimate & pValue & Estimate & pValue & Estimate & pValue & Estimate & pValue \\
\hline Intercept & $\begin{array}{r}100.2663 \\
60\end{array}$ & 0.000000 & $\begin{array}{r}97.40534 \\
0\end{array}$ & 0.000000 & $\begin{array}{r}100.4188 \\
25\end{array}$ & 0.000000 & 2.425663 & 0.963978 & 5.410311 & 0.920276 \\
\hline Child Age & -0.019395 & 0.027243 & -0.019942 & 0.022518 & -0.018752 & 0.028939 & -0.014696 & 0.106447 & -0.014752 & 0.101032 \\
\hline COVID-Model & -2.047941 & 0.599668 & -1.582132 & 0.684468 & -2.147518 & 0.577349 & -2.401197 & 0.551321 & -4.655415 & 0.579965 \\
\hline Maternal Ed. & & & 0.684191 & 0.175319 & 0.624238 & 0.203671 & 1.235866 & 0.099346 & 0.960662 & 0.239703 \\
\hline Male & & & & & -5.524167 & 0.110745 & -4.711777 & 0.195625 & -4.057912 & 0.280674 \\
\hline Gestation & & & & & & & 1.846022 & 0.244516 & 1.776850 & 0.264256 \\
\hline Birth Weight & & & & & & & 2.767081 & 0.234533 & 2.879715 & 0.217461 \\
\hline Male x Model & & & & & & & & & -4.696733 & 0.439359 \\
\hline $\begin{array}{l}\text { Maternal Ed. x } \\
\text { Model }\end{array}$ & & & & & & & & & 0.979381 & 0.441595 \\
\hline VDQ & \multicolumn{2}{|c|}{ Model 1} & \multicolumn{2}{|c|}{ Model 2} & \multicolumn{2}{|c|}{ Model 3} & \multicolumn{2}{|c|}{ Model 4} & \multicolumn{2}{|c|}{ Model 5} \\
\hline BIC & \multicolumn{2}{|c|}{1226.191366} & \multicolumn{2}{|c|}{1226.774931} & \multicolumn{2}{|c|}{1226.374071} & \multicolumn{2}{|c|}{1064.219276} & \multicolumn{2}{|c|}{1067.622234} \\
\hline Term & Estimate & pValue & Estimate & pValue & Estimate & pValue & Estimate & pValue & Estimate & pValue \\
\hline Intercept & $\begin{array}{r}101.3552 \\
48\end{array}$ & 0.000000 & $\begin{array}{r}97.85392 \\
6\end{array}$ & 0.000000 & $\begin{array}{r}102.4927 \\
23\end{array}$ & 0.000000 & 9.015940 & 0.919235 & 5.232606 & 0.952853 \\
\hline Child Age & -0.023287 & 0.097212 & -0.025017 & 0.075669 & -0.022803 & 0.098320 & -0.019001 & 0.222603 & -0.019044 & 0.218556 \\
\hline COVID-Model & -4.743447 & 0.416743 & -3.787672 & 0.518215 & -4.945343 & 0.394431 & -5.742650 & 0.348743 & 1.291075 & 0.926868 \\
\hline Maternal Ed. & & & 0.900950 & 0.232498 & 0.769328 & 0.297368 & 1.885437 & 0.104399 & 2.121262 & 0.143755 \\
\hline Male & & & & & -8.271020 & 0.111431 & -7.058668 & 0.235855 & -4.752222 & 0.472669 \\
\hline Gestation & & & & & & & 1.668816 & 0.518236 & 1.689203 & 0.509866 \\
\hline Birth Weight & & & & & & & 2.607091 & 0.477348 & 2.691657 & 0.460487 \\
\hline Male x Model & & & & & & & & & -7.675059 & 0.445066 \\
\hline $\begin{array}{l}\text { Maternal Ed. x } \\
\text { Model }\end{array}$ & & & & & & & & & -0.650951 & 0.763981 \\
\hline & & & & & & & & & & \\
\hline
\end{tabular}


medRxiv preprint doi: https://doi.org/10.1101/2021.08.10.21261846; this version posted August 11, 2021. The copyright holder for this preprint (which was not certified by peer review) is the author/funder, who has granted medRxiv a license to display the preprint in perpetuity.

All rights reserved. No reuse allowed without permission. 
medRxiv preprint doi: https://doi.org/10.1101/2021.08.10.21261846; this version posted August 11, 2021. The copyright holder for this preprint (which was not certified by peer review) is the author/funder, who has granted medRxiv a license to display the preprint in perpetuity.

All rights reserved. No reuse allowed without permission.

\begin{tabular}{|c|c|c|c|c|c|c|c|c|c|c|}
\hline \multirow{2}{*}{$\begin{array}{c}\text { NVDQ } \\
\text { BIC } \\
\text { Term }\end{array}$} & \multicolumn{2}{|c|}{$\begin{array}{l}\text { Model } 1 \\
\qquad 1179.560518\end{array}$} & \multicolumn{2}{|c|}{$\begin{array}{l}\text { Model } 2 \\
\qquad 1181.306747\end{array}$} & \multicolumn{2}{|c|}{$\begin{array}{l}\text { Model } 3 \\
\qquad 1182.293166\end{array}$} & \multicolumn{2}{|c|}{$\begin{array}{l}\text { Model } 4 \\
\qquad 1028.841428\end{array}$} & \multicolumn{2}{|c|}{$\begin{array}{l}\text { Model } 5 \\
\quad 1032.726942\end{array}$} \\
\hline & Estimate & pValue & Estimate & pValue & Estimate & pValue & Estimate & pValue & Estimate & pValue \\
\hline Intercept & $\begin{array}{r}116.3016 \\
31\end{array}$ & 0.000000 & $\begin{array}{r}115.0556 \\
96\end{array}$ & 0.000000 & $\begin{array}{r}117.8856 \\
55\end{array}$ & 0.000000 & $\begin{array}{r}61.13313 \\
6\end{array}$ & 0.429975 & $\begin{array}{r}62.08237 \\
9\end{array}$ & 0.427188 \\
\hline Child Age & -0.028338 & 0.004479 & -0.029330 & 0.003731 & -0.028594 & 0.004333 & -0.025756 & 0.019887 & -0.025880 & 0.019502 \\
\hline COVID-Model & -4.038943 & 0.429808 & -3.518395 & 0.498170 & -3.961846 & 0.441532 & -3.823532 & 0.505631 & -4.243381 & 0.715800 \\
\hline Maternal Ed. & & & 0.346362 & 0.610793 & 0.252290 & 0.709778 & 0.435734 & 0.675374 & 0.283903 & 0.829291 \\
\hline Male & & & & & -4.714430 & 0.305498 & -4.454052 & 0.390088 & -3.770467 & 0.526075 \\
\hline Gestation & & & & & & & 0.437372 & 0.845883 & 0.418870 & 0.852975 \\
\hline Birth Weight & & & & & & & 4.950345 & 0.127611 & 4.979334 & 0.126569 \\
\hline Male x Model & & & & & & & & & -2.011659 & 0.807478 \\
\hline $\begin{array}{l}\text { Maternal Ed. x } \\
\text { Model }\end{array}$ & & & & & & & & & 0.306913 & 0.861942 \\
\hline
\end{tabular}


medRxiv preprint doi: https://doi.org/10.1101/2021.08.10.21261846; this version posted August 11, 2021. The copyright holder for this preprint (which was not certified by peer review) is the author/funder, who has granted medRxiv a license to display the preprint in perpetuity. All rights reserved. No reuse allowed without permission.

Table 5. Results of our step-wise general linear models investigating the impact of the pandemic on newborns and young infants under 1 year of age born pre-pandemic (before Jan 2019) and during the pandemic (after July 2020). Like results in Table 3, we not again that child born during the pandemic exhibit significantly lower cognitive performance than children born before the pandemic $(p<0.001)$ but that maternal education is a protective factor.

\begin{tabular}{|c|c|c|c|c|c|c|c|c|c|c|}
\hline ELC & \multicolumn{2}{|c|}{ Model 1} & \multicolumn{2}{|c|}{ Model 2} & \multicolumn{2}{|c|}{ Model 3} & \multicolumn{2}{|c|}{ Model 4} & \multicolumn{2}{|c|}{ Model 5} \\
\hline BIC & \multicolumn{2}{|c|}{4574.859772} & \multicolumn{2}{|c|}{4149.364403} & \multicolumn{2}{|c|}{4144.183573} & \multicolumn{2}{|c|}{3562.855010} & \multicolumn{2}{|c|}{3551.746593} \\
\hline Term & Estimate & pValue & Estimate & pValue & Estimate & pValue & Estimate & pValue & Estimate & pValue \\
\hline Intercept & $\begin{array}{r}98.86778 \\
5\end{array}$ & 0.000000 & $\begin{array}{r}89.28601 \\
5\end{array}$ & 0.000000 & $\begin{array}{r}91.23906 \\
0\end{array}$ & 0.000000 & -4.010653 & 0.784098 & -1.668205 & 0.907809 \\
\hline Child Age & -0.007007 & 0.213556 & -0.010064 & 0.080259 & -0.009064 & 0.112001 & -0.008868 & 0.127818 & -0.009452 & 0.100363 \\
\hline COVID-Model & $\begin{array}{r}- \\
10.32953 \\
9\end{array}$ & 0.000000 & $\begin{array}{r}- \\
10.54104 \\
0\end{array}$ & 0.000000 & $\begin{array}{r}- \\
10.59565 \\
1\end{array}$ & 0.000000 & 11.641199 & 0.000000 & $\begin{array}{r}- \\
49.88214 \\
4\end{array}$ & 0.000070 \\
\hline Maternal Ed. & & & 1.955167 & 0.000549 & 1.922774 & 0.000617 & 1.567565 & 0.003179 & 0.990045 & 0.066967 \\
\hline Male & & & & & -3.540089 & 0.006954 & -2.253041 & 0.072222 & -1.719909 & 0.176304 \\
\hline Gestation & & & & & & & 2.280328 & 0.000000 & 2.286943 & 0.000000 \\
\hline Birth Weight & & & & & & & 1.168585 & 0.071640 & 1.233054 & 0.054573 \\
\hline Male x Model & & & & & & & & & -3.132217 & 0.504954 \\
\hline $\begin{array}{l}\text { Maternal Ed. x } \\
\text { Model }\end{array}$ & & & & & & & & & 7.239489 & 0.000396 \\
\hline VDQ & \multicolumn{2}{|c|}{ Model 1} & \multicolumn{2}{|c|}{ Model 2} & \multicolumn{2}{|c|}{ Model 3} & \multicolumn{2}{|c|}{ Model 4} & \multicolumn{2}{|c|}{ Model 5} \\
\hline BIC & \multicolumn{2}{|c|}{5201.271496} & \multicolumn{2}{|c|}{4723.637711} & \multicolumn{2}{|c|}{4723.500494} & \multicolumn{2}{|c|}{4100.649566} & \multicolumn{2}{|c|}{4095.222650} \\
\hline Term & Estimate & pValue & Estimate & pValue & Estimate & pValue & Estimate & pValue & Estimate & pValue \\
\hline Intercept & $\begin{array}{r}104.1753 \\
52\end{array}$ & 0.000000 & $\begin{array}{r}93.96528 \\
6\end{array}$ & 0.000000 & $\begin{array}{r}95.98510 \\
7\end{array}$ & 0.000000 & $\begin{array}{r}- \\
25.91846 \\
6\end{array}$ & 0.320788 & $\begin{array}{r}- \\
23.80413 \\
1\end{array}$ & 0.356684 \\
\hline Child Age & -0.038547 & 0.000114 & -0.046407 & 0.000007 & -0.045482 & 0.000010 & -0.046321 & 0.000018 & -0.047249 & 0.000011 \\
\hline COVID-Model & $\begin{array}{r}- \\
18.52041 \\
7\end{array}$ & 0.000000 & $\begin{array}{r}- \\
18.81946 \\
1\end{array}$ & 0.000000 & $\begin{array}{r}- \\
18.84788 \\
7\end{array}$ & 0.000000 & $\begin{array}{r}- \\
17.28608 \\
0\end{array}$ & 0.000016 & $\begin{array}{r}- \\
76.61423 \\
7\end{array}$ & 0.000738 \\
\hline Maternal Ed. & & & 2.346477 & 0.012257 & 2.267559 & 0.015649 & 1.435786 & 0.123670 & 0.639073 & 0.503533 \\
\hline Male & & & & & -3.241651 & 0.138492 & -0.972784 & 0.658666 & -0.352928 & 0.875775 \\
\hline Gestation & & & & & & & 2.974616 & 0.000141 & 3.023880 & 0.000096 \\
\hline Birth Weight & & & & & & & 1.445501 & 0.205085 & 1.491077 & 0.188468 \\
\hline Male x Model & & & & & & & & & -0.876683 & 0.915634 \\
\hline
\end{tabular}


medRxiv preprint doi: https://doi.org/10.1101/2021.08.10.21261846; this version posted August 11, 2021. The copyright holder for this preprint (which was not certified by peer review) is the author/funder, who has granted medRxiv a license to display the preprint in perpetuity.

All rights reserved. No reuse allowed without permission.

\begin{tabular}{|c|c|c|c|c|c|c|c|c|c|c|}
\hline \multirow{2}{*}{$\begin{array}{c}\text { ELC } \\
\text { BIC } \\
\text { Term }\end{array}$} & \multicolumn{2}{|c|}{$\begin{array}{l}\text { Model } 1 \\
\qquad 4574.859772\end{array}$} & \multicolumn{2}{|c|}{$\begin{array}{l}\text { Model } 2 \\
\qquad 4149.364403\end{array}$} & \multicolumn{2}{|c|}{$\begin{array}{l}\text { Model } 3 \\
\qquad 4144.183573\end{array}$} & \multicolumn{2}{|c|}{$\begin{array}{l}\text { Model } 4 \\
\qquad 3562.855010\end{array}$} & \multicolumn{2}{|c|}{$\begin{array}{l}\text { Model } 5 \\
\qquad 3551.746593\end{array}$} \\
\hline & Estimate & pValue & Estimate & pValue & Estimate & pValue & Estimate & pValue & Estimate & pValue \\
\hline $\begin{array}{l}\text { Maternal Ed. x } \\
\text { Model }\end{array}$ & & & & & & & & & $\begin{array}{r}10.73971 \\
4\end{array}$ & 0.003465 \\
\hline & & & & & & & & & & \\
\hline
\end{tabular}


medRxiv preprint doi: https://doi.org/10.1101/2021.08.10.21261846; this version posted August 11, 2021. The copyright holder for this preprint (which was not certified by peer review) is the author/funder, who has granted medRxiv a license to display the preprint in perpetuity.

All rights reserved. No reuse allowed without permission.

\begin{tabular}{|c|c|c|c|c|c|c|c|c|c|c|}
\hline \multirow{2}{*}{$\begin{array}{c}\text { NVDQ } \\
\text { BIC } \\
\text { Term }\end{array}$} & \multicolumn{2}{|c|}{$\begin{array}{l}\text { Model } 1 \\
\qquad 5210.416306\end{array}$} & \multicolumn{2}{|c|}{$\begin{array}{l}\text { Model } 2 \\
4711.799610\end{array}$} & \multicolumn{2}{|c|}{$\begin{array}{l}\text { Model } 3 \\
\qquad 4705.756790\end{array}$} & \multicolumn{2}{|c|}{$\begin{array}{l}\text { Model } 4 \\
\qquad 4030.416662\end{array}$} & \multicolumn{2}{|c|}{$\begin{array}{l}\text { Model } 5 \\
\qquad 4018.537463\end{array}$} \\
\hline & Estimate & pValue & Estimate & pValue & Estimate & pValue & Estimate & pValue & Estimate & pValue \\
\hline Intercept & $\begin{array}{r}108.7211 \\
97\end{array}$ & 0.000000 & $\begin{array}{r}86.78188 \\
7\end{array}$ & 0.000000 & $\begin{array}{r}90.97108 \\
4\end{array}$ & 0.000000 & $\begin{array}{r}- \\
47.58487 \\
1\end{array}$ & 0.058604 & $\begin{array}{r}- \\
44.25826 \\
8\end{array}$ & 0.074154 \\
\hline Child Age & 0.010480 & 0.248158 & 0.003817 & 0.677479 & 0.005243 & 0.566518 & -0.000470 & 0.958481 & -0.001571 & 0.859054 \\
\hline COVID-Model & $\begin{array}{r}- \\
18.31754 \\
3\end{array}$ & 0.000000 & $\begin{array}{r}- \\
17.46835 \\
5\end{array}$ & 0.000000 & $\begin{array}{r}- \\
17.44950 \\
6\end{array}$ & 0.000000 & $\begin{array}{r}- \\
16.60589 \\
7\end{array}$ & 0.000004 & $\begin{array}{r}- \\
82.32681 \\
4\end{array}$ & 0.000112 \\
\hline Maternal Ed. & & & 4.357814 & 0.000009 & 4.183439 & 0.000016 & 3.910971 & 0.000017 & 2.950514 & 0.001422 \\
\hline Male & & & & & -6.370348 & 0.004507 & -3.660405 & 0.083655 & -2.640348 & 0.221525 \\
\hline Gestation & & & & & & & 3.425030 & 0.000005 & 3.447173 & 0.000003 \\
\hline Birth Weight & & & & & & & 1.066360 & 0.327691 & 1.193121 & 0.268472 \\
\hline Male x Model & & & & & & & & & -4.956133 & 0.503528 \\
\hline $\begin{array}{l}\text { Maternal Ed. x } \\
\text { Model }\end{array}$ & & & & & & & & & $\begin{array}{r}12.32378 \\
7\end{array}$ & 0.000384 \\
\hline & & & & & & & & & & \\
\hline
\end{tabular}


medRxiv preprint doi: https://doi.org/10.1101/2021.08.10.21261846; this version posted August 11, 2021. The copyright holder for this preprint (which was not certified by peer review) is the author/funder, who has granted medRxiv a license to display the preprint in perpetuity.

All rights reserved. No reuse allowed without permission.

Table 6. To determine the influence of maternal pre and post-natal perceived stress, we replaced the COVID-model term in our general linear model with perceived stress scale (PSS) scores self-reported by the child's mother. Overall, we found that this term was not significant and did not contribute to the model fit, suggesting that while stress may play an important biological role in fetal and infant brain development, it does not appear to be solely explain the reduced cognitive scores presented in this work.

\begin{tabular}{|c|c|c|c|c|c|c|}
\hline Postnatal Stress & \multicolumn{2}{|c|}{ ELC } & \multicolumn{2}{|c|}{ VDQ } & \multicolumn{2}{|c|}{ NVDQ } \\
\hline Term & Estimate & pValue & Estimate & pValue & Estimate & pValue \\
\hline PSS & 0.002642 & 0.412242 & 0.003645 & 0.462384 & -0.475995 & 0.613823 \\
\hline Male x PSS & 0.133976 & 0.683750 & 0.206981 & 0.683043 & 0.363321 & 0.406477 \\
\hline Maternal Ed. x PSS & -0.042414 & 0.732502 & -0.273539 & 0.155058 & 0.010763 & 0.948116 \\
\hline Prenatal Stress & \multicolumn{2}{|c|}{ ELC } & \multicolumn{2}{|c|}{ VDQ } & \multicolumn{2}{|c|}{ NVDQ } \\
\hline Term & Estimate & pValue & Estimate & pValue & Estimate & pValue \\
\hline PSS & 1.045007 & 0.157838 & 1.832849 & 0.177509 & 1.712337 & 0.226585 \\
\hline Male x PSS & -0.216887 & 0.555744 & -0.277688 & 0.676534 & -1.050890 & 0.128812 \\
\hline Maternal Ed. x PSS & -0.095475 & 0.496830 & -0.215181 & 0.389910 & -0.067473 & 0.798480 \\
\hline
\end{tabular}


medRxiv preprint doi: https://doi.org/10.1101/2021.08.10.21261846; this version posted August 11, 2021. The copyright holder for this preprint (which was not certified by peer review) is the author/funder, who has granted medRxiv a license to display the preprint in perpetuity.

All rights reserved. No reuse allowed without permission.

Figure 1. Visual overview of all child study visits used in each set of analysis. (a) All children between 0 and 3 years of age; (b) Children with at least one assessment before and one during the pandemic; and (c) Children under 1 year of age born prior to 2019 or after July 2020.

a

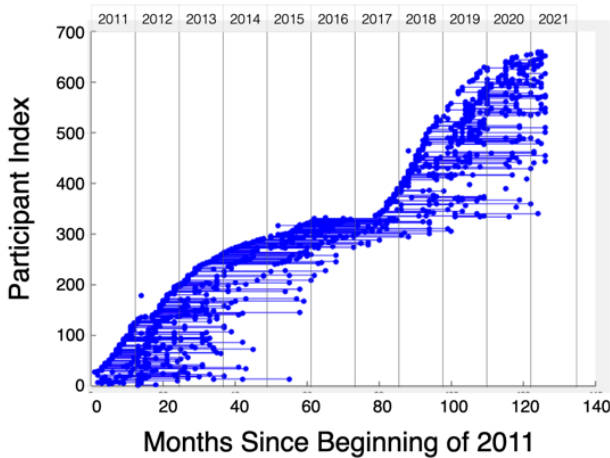

b

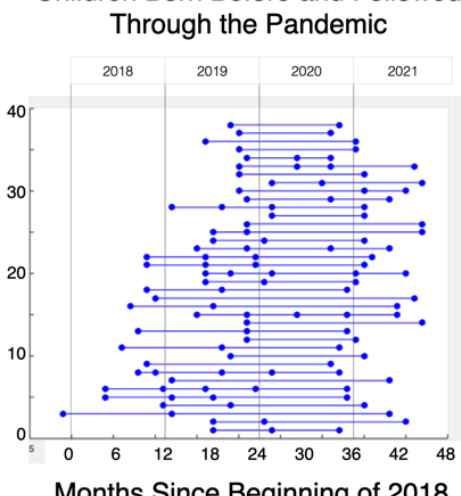

c

Children Born Before and During the Pandemic

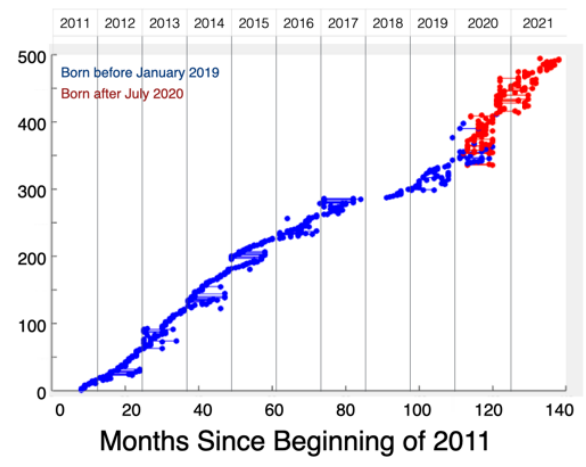


medRxiv preprint doi: https://doi.org/10.1101/2021.08.10.21261846; this version posted August 11, 2021. The copyright holder for this preprint (which was not certified by peer review) is the author/funder, who has granted medRxiv a license to display the preprint in perpetuity.

All rights reserved. No reuse allowed without permission.

Figure 2. Visual comparison and trends of yearly ELC, VDQ, and NVDQ composite scores of the Mullen Scales of Early Learning. In each panel, the black line and gray bar represent the expect mean (100) and standard deviation (15). Overall, we note a consistent trend of measures from 2011 to 2019 , and then a significant decline in 2020 and 2021, corresponding to the COVID-19 pandemic.

Significance of these reductions, controlling for important confounders, is presented in Table 3.
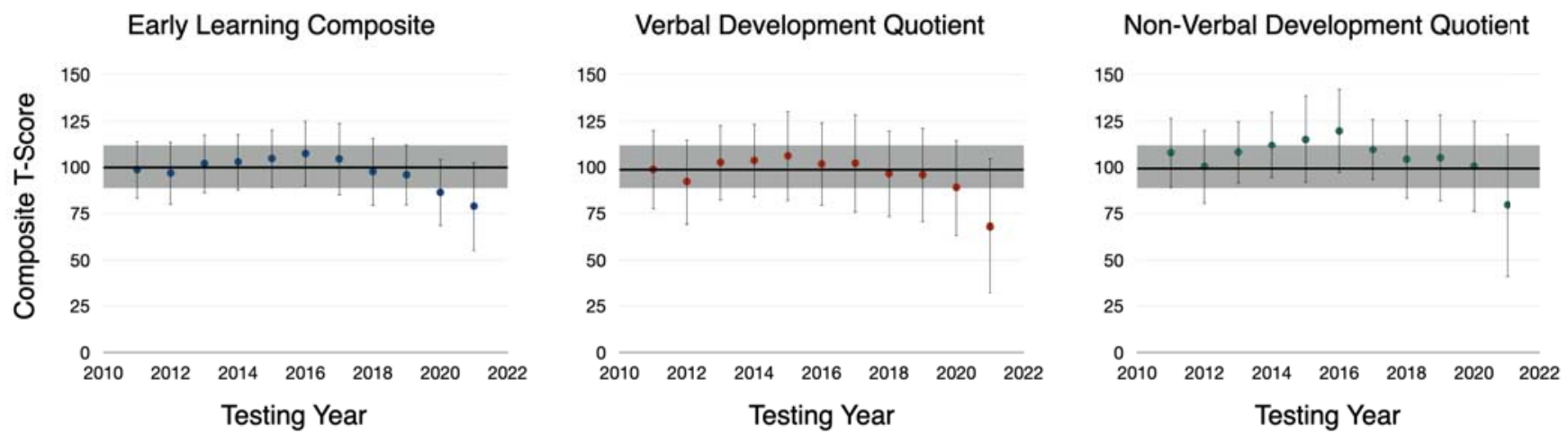
medRxiv preprint doi: https://doi.org/10.1101/2021.08.10.21261846; this version posted August 11, 2021. The copyright holder for this preprint (which was not certified by peer review) is the author/funder, who has granted medRxiv a license to display the preprint in perpetuity.

All rights reserved. No reuse allowed without permission.

Figure 3. Comparison of yearly gestation duration and child birth weights for children tested in our study. Overall, we find no significant change between pre- or during the pandemic.
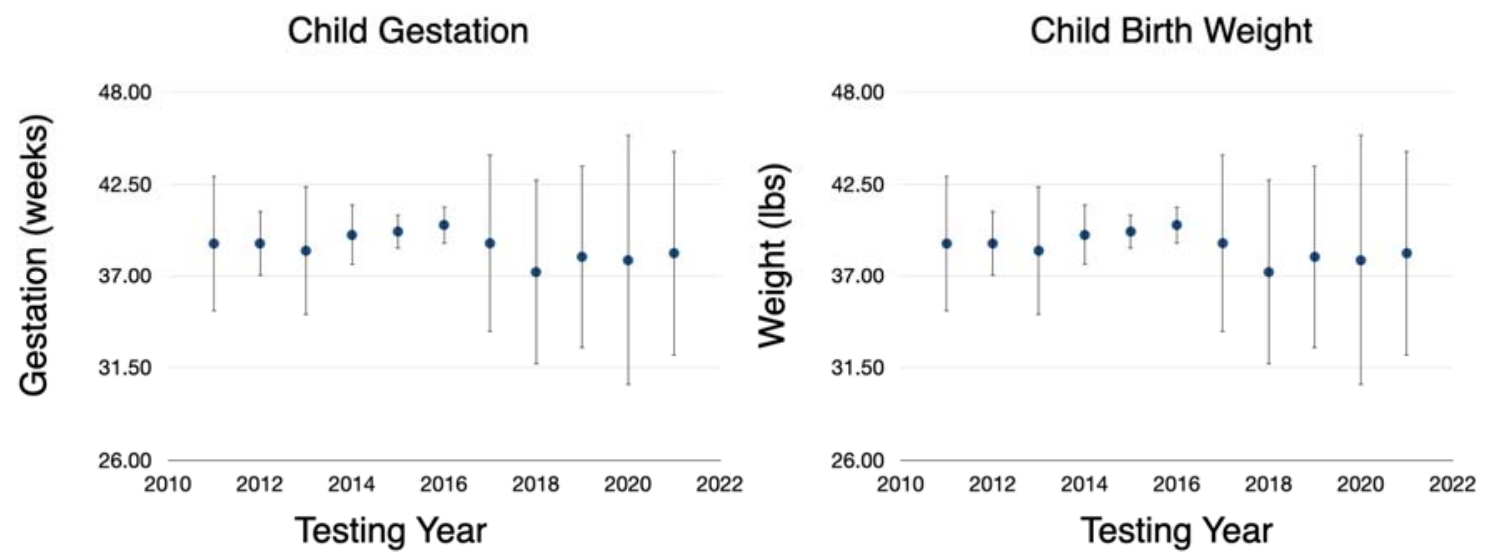
medRxiv preprint doi: https://doi.org/10.1101/2021.08.10.21261846; this version posted August 11, 2021. The copyright holder for this preprint (which was not certified by peer review) is the author/funder, who has granted medRxiv a license to display the preprint in perpetuity.

All rights reserved. No reuse allowed without permission.

Figure 4. Plots of individual longitudinal ELC, VDQ, and NVDQ measures in the children born before the pandemic (2018) with at least 1 pre- and during pandemic measure. We do not observe any clear increasing or decrease trends through the pandemic.

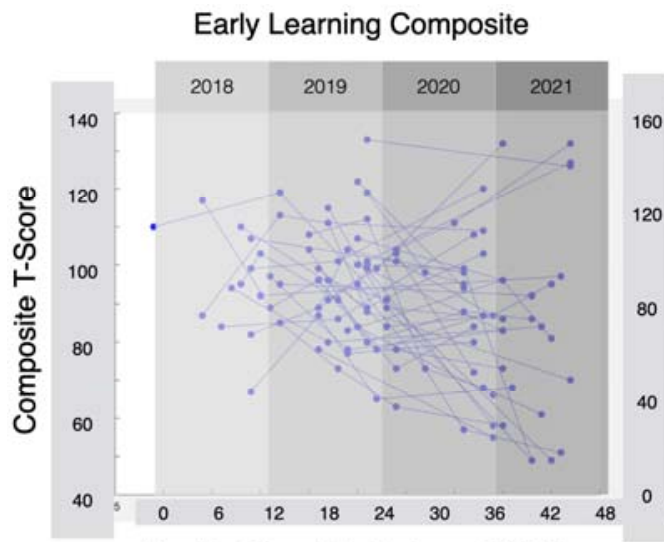

Months Since Beginning of 2018
Verbal Development Quotient

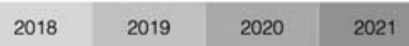

60

120

80

40

0

Months Since Beginning of 2018
Non-Verbal Development Quotient

\begin{tabular}{|l|l|l|l|}
\hline 2018 & 2019 & 2020 & 2021 \\
\hline
\end{tabular}

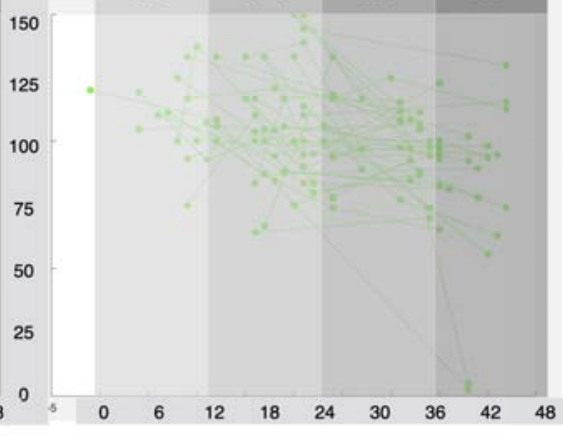

Months Since Beginning of 2018 
medRxiv preprint doi: https://doi.org/10.1101/2021.08.10.21261846; this version posted August 11, 2021. The copyright holder for this preprint (which was not certified by peer review) is the author/funder, who has granted medRxiv a license to display the preprint in perpetuity.

All rights reserved. No reuse allowed without permission.

Figure 5. (a) Yearly maternal PSS scores, obtained during pregnancy and following child birth. In contrast to other studies reported at the beginning of the pandemic, we do not observe a significant increase in maternal stress in 2020 or 2021 . We also examined maternal education as a marker of socioeconomic status of families tested in each year (b). Like PSS, we found no significant increase or decrease in families tested during the COVID-19 pandemic.

a

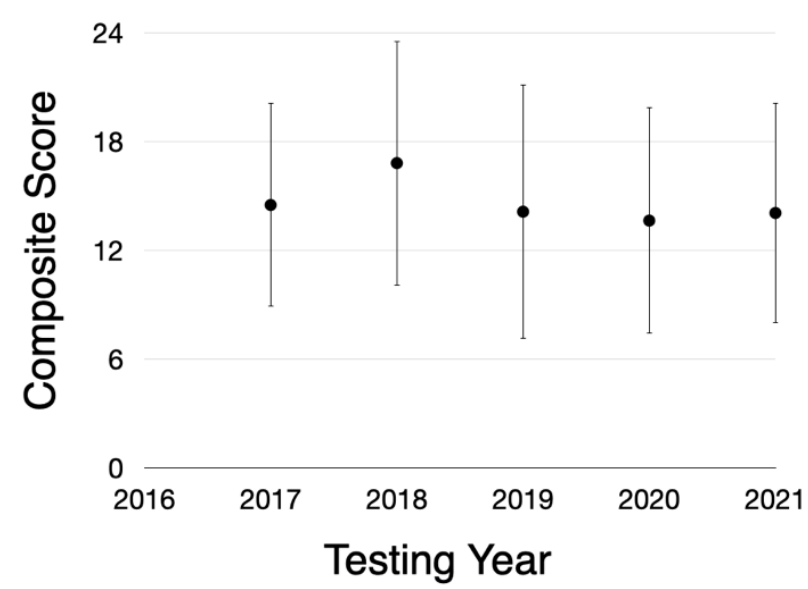

b Maternal Education

8

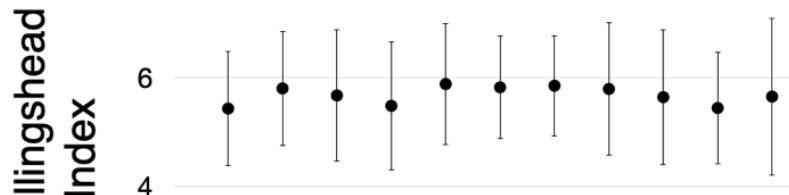

2

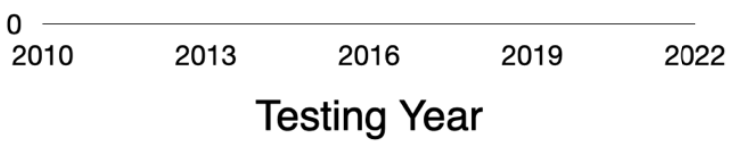


medRxiv preprint doi: https://doi.org/10.1101/2021.08.10.21261846; this version posted August 11, 2021. The copyright holder for this preprint (which was not certified by peer review) is the author/funder, who has granted medRxiv a license to display the preprint in perpetuity. All rights reserved. No reuse allowed without permission.

\section{References}

1. Hoang, A., et al., COVID-19 in 7780 pediatric patients: A systematic review. EClinicalMedicine, 2020. 24: p. 100433.

2. Zimmermann, P. and N. Curtis, Why is COVID-19 less severe in children? A review of the proposed mechanisms underlying the age-related difference in severity of SARS-CoV-2 infections. Arch Dis Child, 2020.

3. Egan, S.M., et al., Missing Early Education and Care During the Pandemic: The SocioEmotional Impact of the COVID-19 Crisis on Young Children. Early Child Educ J, 2021: p. 110.

4. Engzell, P., A. Frey, and M.D. Verhagen, Learning loss due to school closures during the COVID-19 pandemic. Proc Natl Acad Sci U S A, 2021. 118(17).

5. Jalongo, M.R., The Effects of COVID-19 on Early Childhood Education and Care: Research and Resources for Children, Families, Teachers, and Teacher Educators. Early Child Educ J, 2021: p. 1-12.

6. Yomoda, K. and S. Kurita, Influence of social distancing during the COVID-19 pandemic on physical activity in children: A scoping review of the literature. J Exerc Sci Fit, 2021. 19(3): p. 195-203.

7. Schmidt, S.C.E., et al., Physical activity and screen time of children and adolescents before and during the COVID-19 lockdown in Germany: a natural experiment. Sci Rep, 2020. 10(1): p. 21780.

8. Marques de Miranda, D., et al., How is COVID-19 pandemic impacting mental health of children and adolescents? Int J Disaster Risk Reduct, 2020. 51: p. 101845.

9. Araujo, L.A., et al., The potential impact of the COVID-19 pandemic on child growth and development: a systematic review. J Pediatr (Rio J), 2021. 97(4): p. 369-377.

10. Kirby, T., Evidence mounts on the disproportionate effect of COVID-19 on ethnic minorities. Lancet Respir Med, 2020. 8(6): p. 547-548.

11. Tai, D.B.G., et al., The Disproportionate Impact of COVID-19 on Racial and Ethnic Minorities in the United States. Clin Infect Dis, 2021. 72(4): p. 703-706.

12. Khatana, S.A.M. and P.W. Groeneveld, Health Disparities and the Coronavirus Disease 2019 (COVID-19) Pandemic in the USA. J Gen Intern Med, 2020. 35(8): p. 2431-2432.

13. Casey, B.J., J.N. Giedd, and K.M. Thomas, Structural and functional brain development and its relation to cognitive development. Biol Psychol, 2000. 54(1-3): p. 241-57.

14. Johnson, M.H., Functional brain development in humans. Nat Rev Neurosci, 2001. 2(7): p. 475-83.

15. Luby, J., et al., The effects of poverty on childhood brain development: the mediating effect of caregiving and stressful life events. JAMA Pediatr, 2013. 167(12): p. 1135-42.

16. Monk, C., M.K. Georgieff, and E.A. Osterholm, Research review: maternal prenatal distress and poor nutrition - mutually influencing risk factors affecting infant neurocognitive development. J Child Psychol Psychiatry, 2013. 54(2): p. 115-30.

17. Blair, C. and C.C. Raver, Poverty, Stress, and Brain Development: New Directions for Prevention and Intervention. Acad Pediatr, 2016. 16(3 Suppl): p. S30-6.

18. Pulli, E.P., et al., Prenatal exposures and infant brain: Review of magnetic resonance imaging studies and a population description analysis. Hum Brain Mapp, 2019. 40(6): p. 1987-2000.

19. Kolb, B., Brain and behavioural plasticity in the developing brain: Neuroscience and public policy. Paediatr Child Health, 2009. 14(10): p. 651-2.

20. He, S., et al., Early enriched environment promotes neonatal GABAergic neurotransmission and accelerates synapse maturation. J Neurosci, 2010. 30(23): p. 7910-6. 
medRxiv preprint doi: https://doi.org/10.1101/2021.08.10.21261846; this version posted August 11, 2021. The copyright holder for this preprint (which was not certified by peer review) is the author/funder, who has granted medRxiv a license to display the preprint in perpetuity. All rights reserved. No reuse allowed without permission.

21. Fields, R.D., A new mechanism of nervous system plasticity: activity-dependent myelination. Nat Rev Neurosci, 2015. 16(12): p. 756-67.

22. Ismail, F.Y., A. Fatemi, and M.V. Johnston, Cerebral plasticity: Windows of opportunity in the developing brain. Eur J Paediatr Neurol, 2017. 21(1): p. 23-48.

23. Dobbing, J., The Influence of Early Nutrition on the Development and Myelination of the Brain. Proc R Soc Lond B Biol Sci, 1964. 159: p. 503-9.

24. Pollitt, E., Poverty and child development: relevance of research in developing countries to the United States. Child Dev, 1994. 65(2 Spec No): p. 283-95.

25. Bradley, R.H. and R.F. Corwyn, Socioeconomic status and child development. Annu Rev Psychol, 2002. 53: p. 371-99.

26. Swain, J.E., et al., Brain basis of early parent-infant interactions: psychology, physiology, and in vivo functional neuroimaging studies. J Child Psychol Psychiatry, 2007. 48(3-4): p. 262-87.

27. Poulain, T., M. Vogel, and W. Kiess, Review on the role of socioeconomic status in child health and development. Curr Opin Pediatr, 2020. 32(2): p. 308-314.

28. Rees, S. and T. Inder, Fetal and neonatal origins of altered brain development. Early Hum Dev, 2005. 81(9): p. 753-61.

29. Bonnier, C., Evaluation of early stimulation programs for enhancing brain development. Acta Paediatr, 2008. 97(7): p. 853-8.

30. de Oliveira, K.H.D., et al., Household food insecurity and early childhood development: Systematic review and meta-analysis. Matern Child Nutr, 2020. 16(3): p. e12967.

31. Kinsella, M.T. and C. Monk, Impact of maternal stress, depression and anxiety on fetal neurobehavioral development. Clin Obstet Gynecol, 2009. 52(3): p. 425-40.

32. Glover, V., et al., Prenatal maternal stress, fetal programming, and mechanisms underlying later psychopathology-A global perspective. Dev Psychopathol, 2018. 30(3): p. 843-854.

33. Relier, J.P., Influence of maternal stress on fetal behavior and brain development. Biol Neonate, 2001. 79(3-4): p. 168-71.

34. Beydoun, H. and A.F. Saftlas, Physical and mental health outcomes of prenatal maternal stress in human and animal studies: a review of recent evidence. Paediatr Perinat Epidemiol, 2008. 22(5): p. 438-66.

35. Buss, C., et al., The Role of Stress in Brain Development: The Gestational Environment's LongTerm Effects on the Brain. Cerebrum, 2012. 2012: p. 4.

36. King, S. and D.P. Laplante, The effects of prenatal maternal stress on children's cognitive development: Project Ice Storm. Stress, 2005. 8(1): p. 35-45.

37. Lebel, C., et al., Corrigendum to elevated depression and anxiety symptoms among pregnant individuals during the COVID-19 pandemic journal of affective disorders 277 (2020) 5-13. J Affect Disord, 2021. 279: p. 377-379.

38. Loades, M.E., et al., Rapid Systematic Review: The Impact of Social Isolation and Loneliness on the Mental Health of Children and Adolescents in the Context of COVID-19. J Am Acad Child Adolesc Psychiatry, 2020. 59(11): p. 1218-1239 e3.

39. Provenzi, L., et al., Prenatal maternal stress during the COVID-19 pandemic and infant regulatory capacity at 3 months: A longitudinal study. Dev Psychopathol, 2021: p. 1-9.

40. $\quad$ E.M., M., Mullen Scales of Early Learning. 1995, Circle Pines, MN: American Guidance Services, Inc.

41. Hauser, R.M., Measuring socioeconomic status in studies of child development. Child Dev, 1994. 65(6): p. 1541-5.

42. Harvey, E.M., et al., Association of Preterm Birth Rate With COVID-19 Statewide Stay-atHome Orders in Tennessee. JAMA Pediatr, 2021. 175(6): p. 635-637. 
medRxiv preprint doi: https://doi.org/10.1101/2021.08.10.21261846; this version posted August 11, 2021. The copyright holder for this preprint (which was not certified by peer review) is the author/funder, who has granted medRxiv a license to display the preprint in perpetuity.

All rights reserved. No reuse allowed without permission.

43. Vrieze, S.I., Model selection and psychological theory: a discussion of the differences between the Akaike information criterion (AIC) and the Bayesian information criterion (BIC). Psychol Methods, 2012. 17(2): p. 228-43.

44. Cohen, S., T. Kamarck, and R. Mermelstein, A global measure of perceived stress. J Health Soc Behav, 1983. 24(4): p. 385-96.

45. Abdoli, A., et al., The COVID-19 pandemic, psychological stress during pregnancy, and risk of neurodevelopmental disorders in offspring: a neglected consequence. J Psychosom Obstet Gynaecol, 2020. 41(3): p. 247-248.

46. Cox, J.L., J.M. Holden, and R. Sagovsky, Detection of postnatal depression. Development of the 10-item Edinburgh Postnatal Depression Scale. Br J Psychiatry, 1987. 150: p. 782-6.

47. Cella, D., et al., PROMIS((R)) Adult Health Profiles: Efficient Short-Form Measures of Seven Health Domains. Value Health, 2019. 22(5): p. 537-544.

48. Balaji, A.B., et al., Social support networks and maternal mental health and well-being. J Womens Health (Larchmt), 2007. 16(10): p. 1386-96.

49. Slykerman, R.F., et al., Maternal stress, social support and preschool children's intelligence. Early Hum Dev, 2005. 81(10): p. 815-21.

50. Bezerra, A.C.V., et al., Factors associated with people's behavior in social isolation during the COVID-19 pandemic. Cien Saude Colet, 2020. 25(suppl 1): p. 2411-2421.

51. Fiorillo, A. and P. Gorwood, The consequences of the COVID-19 pandemic on mental health and implications for clinical practice. Eur Psychiatry, 2020. 63(1): p. e32.

52. Calbi, M., et al., The consequences of COVID-19 on social interactions: an online study on face covering. Sci Rep, 2021. 11(1): p. 2601.

53. Loman, M., et al., "How to" operate a pediatric neuropsychology practice during the COVID19 pandemic: Real tips from one practice's experience. Child Neuropsychol, 2021. 27(2): p. 251-279.

54. Clark, E., et al., Disproportionate impact of the COVID-19 pandemic on immigrant communities in the United States. PLoS Negl Trop Dis, 2020. 14(7): p. e0008484.

55. Finch, W.H. and M.E. Hernandez Finch, Poverty and Covid-19: Rates of Incidence and Deaths in the United States During the First 10 Weeks of the Pandemic. Front Sociol, 2020. 5: p. 47. 